tissues and unpleasant odour of meat cuts during cooking, even when boar taint was detected as objectionable in mesenteric or in kidneyfat.

It seems important to put much attention, in the future, to the odours of pork (boar taint or, mainly, "pig taint ". The need for determination of "odour profile ", such it has been stated in this study, is emphasized to define more precisely the carcass quality of pigs.

\title{
CARACTÈRES de CLASSIFICATION DES CARCASSES DE PORCS ISSUS DE CROISEMENTS « COMMERCIAUX »
}

\author{
B. DESMOULIN, F. POLINE et Y. MAURY
}

\author{
Station de Recherches sur l'Élevage des Porcs, \\ Centre national de Recherches zootechniques, I. N.R. A., \\ 78350 Jouy en Josas \\ Établissements Sanders, \\ 91 - Juvisy-sur-Orge
}

\section{RÉSUMÉ}

60 carcasses de pores issus de trois types de croisements commerciaux $\mathrm{T}$, P et H sont étudiées comme échantillon représentatif du classement commercial (I. T. P) établi en abattoir industriel sur 300 porcs (produits par les établissements Sanders). Après la découpe normalisée des demicarcasses, la densité des morceaux séparés : jambon, "rein de porc " ou ensemble longe + bardière, poitrine hachage et jambonneau, est déterminée au C. N. R. Z. selon les méthodes définies antérieurement (Desmoulin, r97o). Des abaques de classification sont construites suivant le caractère de densité du "rein de porc " (DESmOulin et BouRDON, I971) : elles définissent une répartition individuelle des carcasses dans 6 classes d'état d'engraissement comprises entre r,030-1,035 (classe I) et I,055-I,060 (classe VI). Les caractères associés à cette discrimination suivant la densité sont ainsi précisés pour les porcs gras et pour les porcs maigres.

I. L'épaisseur du lard dorsal est un critère de différenciation des porcs gras (classes I à III) alors que la longueur de carcasse est un caractère discriminant des porcs maigres (classe III à VI). La sélection des porcs maigres, sur le critère d'épaisseur du lard dorsal, est ainsi limitée. Toutefois, sur ces deux caractères, on note une influence marquée du type génétique : le type $\mathrm{H}$ présente ainsi une carcasse très courte avec des masses maigres globuleuses caractéristiques d'un porc maigre de type "culard ". Le type $\mathrm{P}$ présente inversement une carcasse très longue sans présenter toutefois une adiposité (poids de bardière) très réduite et des masses maigres très développées ; c'est un porc de type "baconer ". La limite des caractères de conformation des carcasses est ainsi précisée : la longueur de carcasse doit être associée à l'épaisseur du lard dorsal.

2. La densité du " rein de porc ", très représentative de l'état d'engraissement de la carcasse totale (sans pieds, ni tête), permet de justifier l'utilisation du rapport longe/bardière comme caractère simple d'estimation de l'état d'engraissement des carcasses. Cependant, la faible reproductivité des résultats de la découpe est mise en évidence : la séparation non aléatoire des masses maigres, longe, et des masses grasses, bardière, conduit à majorer de $r, 5$ points le pourcentage 
de jambon + longe en abattoir industriel par rapport aux résultats obtenus à l'abattoir du C. N. R. Z. Une variation inverse concerne bien entendu le pourcentage de bardière + panne.

3. La limite des critères de la découpe-testage est par ailleurs précisée. Nous remarquons d'abord que la variation relative du poids des morceaux (format) est 3 fois plus faible que celle des poids immergés des morceaux (densité et composition tissulaire). Les critères de la découpe caractérisent ainsi une amplitude de variation comprise entre 52 et $57 \mathrm{p}$. ıoo de morceaux maigres, entre 19 et $\mathrm{I} 3 \mathrm{p}$. Ioo de morceaux gras. Le seuil de discrimination du point (ou p. Ioo) de cette variation est lié directement à la variation du poids net de la carcasse. Le rendement étant plus élevé chez les porcs gras, les masses grasses sont sous-estimées; invcrsement, les masses maigres des porcs maigres sont surestimées par ces modes d'expression peu conformes aux différences d'état d'engraissement des carcasses. Alors que la castration du porc mâle tend à niveler les différences entre les 3 types génétiques, la discrimination est nettement établie sur les carcasses des porcs femelles. Les critères classiquement utilisés pour l'appréciation des carcasses apparaissent généralement très insuffisants pour la sélection des porcs maigres (lors du progeny-test). Pour déterminer l'effet de l'hétérosis, comme pour adapter l'alimentation aux niveaux différents des potentialités génétiques, une évolution des méthodes de mesure de l'état d'engraissement des carcasses est indispensable.

\section{SUMMARY}

\section{GRADING CHARACTERS OF CROSSBRED PIG CARCASSES}

60 carcasses of pigs from three types of commercial crossbreedings $(\mathrm{T}, \mathrm{P}$ and $\mathrm{H})$ were studied as a representative sample of commercial grading carried out in an industrial slaughterhouse with 300 pigs (produced by the firm Sanders). After standard cutting of half-carcasses, the specific gravity of the cuts : ham, "rein de porc " or loin + backfat, belly and shoulder-ham, was determined at the C. N. R. Z. according to previously established methods (Desmoulin, I970). Grading graphs were developed according to the specific gravity character of the " rein de porc " (Desmoulin, Bourdon, 1971); they showed an individual distribution of the carcasses into 6 classes of fattening state ranging between I 030 and I 035 (class I) and I $055^{-I}$ o60 (class VI). Thus, the characters associated with this discrimination according to the specific gravity were determined for fat and for lean pigs.

I. Backfat thickness represents a criterium for the determination of fat pigs (classes I and III) whereas carcass length is a character allowing cliscrimination of lean pigs (classes III to VI). Selection of lean pigs on backfat thickness is thus eliminated. However, a marked influence of the genetic type on these two characters is noticed : type $\mathrm{H}$ has a very short carcass with globular lean masses characteristic of lean pigs of the type " double muscle ". Inversely, type P has a very long carcass, but without reduced adiposity (backfat weight) and without well developed lean masses; it is a pig of the "bacon " type. The limit of the carcass conformation characters has been defined as follows : carcass length must be associated with backfat thickness.

2. The specific gravity of the "rein de porc ", very representative of the total carcass fattening state (without feet and head) justifies the utilization of the loin/backfat ratio as a simple character for carcass grading. However, the repeatability of the results of the cutting is very low : non aleatory separation of the lean masses (loin) and of the fat masses (backfat) leads to a majoration of $\mathrm{T} .5$ points of the ham + loin percentage in the case of an industrial slaughterhouse compared with the results obtained in C. N. R. Z. The backfat + flarefat percentage is naturally subjected to complementary inverse variation.

3. The limit of the cutting-testing criteria has also been determined. It has been noticed that the relative variation in the weight of the cuts (size) is three times lower than that of the 
immerged weights of the cuts (specific gravity and tissular composition). The cutting criteria thus determine an amplitude of variation between $5^{2}$ and $57 \mathrm{p}$. Ioo of lean cuts, between I9 and $13 \mathrm{p}$. Ioo fat cuts. The discrimination threshold of the point (or I p. roo) of this variation was directly related to the variation of the carcass net weight. As the yield was higher in fat pigs, the fat masses were underestimated ; inversely, the lean masses of the lean pigs were overestimated by these modes of expression that did not correspond with the carcass fattening state differences. Castration of male pigs tended to equalize the differences between the 3 genetic types, whereas the discrimination was clearly established with female pig carcasses. The criteria classically used to estimate the carcasses generally appeared to be insufficient for the selection of lean pigs (at the moment of progeny-testing). Further development of the methods used to measure the fattening state of the carcasses would be necessary for determining the heterosis effect as well as for adapting the feeding of the animals to the different levels of genetic potentiality.

\title{
ÉTUDE DU PROFIL DE LA COUCHE DE LARD DU POLC MALE ENTIER DE RACE « LARGE-WHITE » DE 80 ET $100 \mathrm{KG}$
}

\author{
B.-L. DUMONT \\ Laboratoire de Recherches sur la Viande, \\ Centre national de Recherches zootechniques, I. N.R. A., \\ 78350 Jouy en Josas
}

\section{RÉSUMMÉ}

La couche de graisse sous-cutanéc au niveau de la colonne vertébrale (lard dorsal) de porcs mâles de race Large White de 80 et Ioo $\mathrm{kg}$ de poids vif montre un maximum au niveau de la seconde côte et un minimum en avant de la dernière côte. Les profils de lard dorsal sont semblables chez les animaux de 80 et Ioo kg, mais l'augmentation d'épaisseur, entre ces deux stades, n'est significative qu'au niveau de garrot et de l'attache du rein. L'augmentation d'épaisseur moyenne du lard (9 p. roo) et celle de la longueur de la carcasse ( $6 \mathrm{p}$. тоo) n'explique que très partiellement l'accroissement de la "bardière " (3o p. Ioo environ). Les relations entre l'épaisseur du lard aux divers niveaux et le poids de la "bardière " sont très différents chez les mâles castrés et les entiers. Pour ces derniers, le milieu du rein est la zone où les corrélations sont les plus fortes. Les méthodes d'appréciation de l'adiposité à partir de l'épaisseur de lard en usage pour les autres types sexuels ne peuvent être transposées aux mâles entiers.

\section{SUMMARY}

\section{STUDY OF BACKFAT THICKNESS ALONG THE BACKBONE OF NON CASTRATED LARGE WHITE MALE PIGS OF 80 AND IOO KG LIVE WEIGHT}

Backfat thickness in Large White male pigs of 80 and $100 \mathrm{~kg}$ live weight was maximum at second rib level and minimum in front of the last rib. The backfat profiles were similar in animals of 80 and $100 \mathrm{~kg}$, but the increase in thickness, between these two stages, was only significant 